\title{
Anatomi Sekuritisasi Pandemi COVID-19: Komparasi antara Pakistan dan Indonesia
}

\author{
Alfin Febrian Basundoro', Lazarus Andja Karunia ${ }^{2}$ \\ ${ }^{1}$ Universitas Gadjah Mada, alfinfb@gmail.com \\ ${ }^{2}$ Universitas Gadjah Mada, lazarusandjakarunia@gmail.com
}

\begin{abstract}
ABSTRAK
COVID-19 yang melanda dunia hampir setahun terakhir mengakibatkan krisis yang masif di berbagai negara. Hingga Oktober 2020, WHO mencatat lebih dari 37 juta orang terkonfirmasi positif COVID-19 dengan lebih dari 11 juta kasus aktif. ${ }^{1}$ Tidak hanya sektor kesehatan masyarakat, pandemi ini juga menghancurkan sektor strategis lainnya, seperti ekonomi dan sosial-politik. Negara-negara di dunia dipaksa untuk melakukan rangkaian pembentukan kebijakan yang dapat seefektif mungkin mengurangi dampak pandemi terhadap warga negaranya, sekaligus mengatasi aneka permasalahan yang mengikuti pandemi tersebut dalam aneka sektor. ${ }^{2}$ Makalah ini berusaha menganalisis secara komparatif dua negara berkembang yang mengalami dampak pandemi COVID-19 yang cukup signifikan, yakni Pakistan dan Indonesia. Sejumlah kemiripan kedua negara, seperti masifnya jumlah penduduk, kolaborasi sipil-militer yang cukup signifikan, penerapan kunci sementara (lockdown) parsial, dan penerapan sejumlah kebijakan lain yang bertujuan untuk menyelamatkan ekonomi nasional menjadi pertimbangan pemilihan topik ini. Sekuritisasi yang dilakukan oleh kedua negara sebagai upaya untuk memosisikan pandemi COVID-19 sebagai isu keamanan nontradisional yang pelik juga menjadi sorotan global terkait bagaimana negara berkembang mengatasi pandemi, dan karenanya, menarik untuk dianalisis. Copenhagen School akan menjadi konsep dasar dalam menganalisis sekuritisasi kedua negara secara komparatif, menekankan pada tahapan-tahapan sekuritisasi. ${ }^{3}$ Nantinya, penelitian ini akan membandingkan seberapa efektif tindakan sekuritisasi yang dilakukan oleh kedua negara dalam mengimplementasikan kebijakan penanganan pandemi COVID-19. Tidak hanya itu, penelitian ini juga mencakup apa saja faktor yang menentukan keberhasilan atau kegagalan sekuritisasi kedua negara. Orientasi penelitian akan cukup banyak berkutat pada hubungan sipil-militer kedua negara dan relasinya dalam desekuritisasi, juga sedikit menyentuh isu demokratisasi penanganan COVID-19.
\end{abstract}

Kata kunci: COVID-19, Indonesia, Pakistan, Sekuritisasi, Penanganan Pandemi

\section{ABSTRACT}

The COVID-19 pandemic that engulfed the globe for almost the past year produced a massive crisis in various nations. Until October 2020, WHO noted that there are more than 37 million people with confirmed COVID-19 positive cases, with more than 11 million active cases. Not only does the public health sector get hit, but this pandemic also pulverized other strategic sectors such as the economy and the socio-political realm. Countries around the world are forced to enact policies as effectively as possible to dampen the pandemic's effects on its citizens, as well as solving various other issues in other sectors. This research tries to analyze two developing countries comparatively, both facing significant challenges from the COVID-19 pandemic: Pakistan

\footnotetext{
${ }^{1}$ World Health Organization, "WHO Coronavirus Disease (COVID-19) Dashboard," 7 Oktober 2020, https://covid19.who.int.

${ }^{2}$ Alex Woodward, “5.4m Americans Lost Health Insurance during Coronavirus Pandemic," The Independent, 14 Juli 2020, diakses pada 7 Oktober 2020,

https://www.independent.co.uk/news/world/americas/coronavirus-health-insurance-pandemic-families-usa-reporta9617226.html.

${ }^{3}$ Holger Stritzel, "Securitization Theory and the Copenhagen School," dalam Security in Translation: Securitization Theory and the Localization of Threat, ed. oleh Holger Stritzel, New Security Challenges Series (London: Palgrave Macmillan UK, 2014), 11-37, https://doi.org/10.1057/9781137307576_2.
} 
and Indonesia. Several similarities between them such as population size, significant civil-military collaboration, application of partial lockdown, and the execution of several policies to save the national economy become part of the calculus to pick them. Securitization that is done by both countries position COVID-19 as a peculiar non-traditional security issue that is also viewed by the world in great detail. Copenhagen School will be the main foundational concept in analyzing the securitization of both countries comparatively, focusing on the phases of securitization. This research will compare just how effective securitization measures are enacted in both countries in implementing their policies to face COVID-19, also observe factors that determine the success or failure of securitization in both countries. The orientation of the research will have a significant portion that tackles on the civil-military relations of both countries and its relations to de-securitization and also a little touch on the democratization of COVID-19 measures.

Keywords: COVID-19, Indonesia, Pakistan, Securitization, Pandemic Measures

\section{Pendahuluan}

Dampak pandemi COVID-19 telah menjangkau berbagai sektor secara masif. Alhasil, para pengambil kebijakan di seluruh dunia, khususnya pemerintah, perlu merumuskan kebijakan yang mampu seefektif mungkin mereduksi dampak pandemi terhadap masyarakat. Perumusan dan implementasi kebijakan penanganan pandemi tentunya membutuhkan suatu proses persepsi oleh pemerintah, yakni sekuritisasi. Dengan sekuritisasi COVID-19 sebagai ancaman keamanan nontradisional terhadap masyarakat, pemerintah sebagai pengambil kebijakan dapat menciptakan kesadaran umum akan dampak pandemi, sehingga penanganannya dapat dilakukan secara efektif. Makalah ini akan menggunakan pendekatan komparatif, di mana Indonesia dan Pakistan akan menjadi dua negara fokus analisis. Alasan penulis memilih kedua negara karena adanya kemiripan signifikan di antara keduanya terkait penanganan COVID-19, seperti masifnya jumlah penduduk, kolaborasi sipil-militer yang cukup signifikan, penerapan kunci sementara (lockdown) parsial, dan penerapan sejumlah kebijakan lain yang bertujuan untuk menyelamatkan ekonomi nasional menjadi pertimbangan pemilihan topik ini.

Pertanyaan penelitian yang akan dijawab dalam makalah ini adalah bagaimana anatomi sekuritisasi pandemi COVID-19 yang terjadi di Pakistan dan Indonesia dan seberapa efektif sekuritisasi tersebut dilakukan oleh pemerintah masing-masing negara. Argumen kami adalah bahwa baik Pemerintah Indonesia maupun Pakistan memiliki anatomi sekuritisasi yang serupa. ${ }^{4}$ Selain itu, persamaan keduanya antara lain mencakup aspek dampak dan penanganan dari pandemi tersebut, seperti jumlah kasus positif yang mencapai ratusan ribu, sektor ekonomi yang mengalami hambatan akibat pandemi ini, kebijakan kunci sementara (lockdown) parsial, hingga adanya relasi spesifik antara pihak sipil dan militer dalam penanganan pandemi sebagai salah satu aspek penting dalam menjelaskan proses sekuritisasi. Selain itu, keduanya relatif lamban dalam menanggapi pandemi ini dan sempat terjadi lonjakan jumlah kasus akibat keterlambatan penanganan tersebut.

Meski demikian, perbedaan signifikan di antara keduanya, di mana Pakistan mampu melakukan sekuritisasi yang cukup efektif dan berhasil "melandaikan” grafik kasus positif, sejak Juli

\footnotetext{
${ }^{4}$ Yulia Anggraeni, Lia Maulia Indrayani, dan Ypsi Soeria Soemantri, “The Expressive Speech Act on Ridwan Kamil's Comments in Instagram Posting about First COVID-19 Case in Indonesia," Journal of English Education and Teaching 4, no. 3 (2 September 2020): 368-85, https://doi.org/10.33369/jeet.4.3.368-385.
} 
2020. ${ }^{5}$ Kebijakan smart lockdown yang digadang menjadi strategi untuk menurunkan angka penularan COVID-19 di Pakistan menuai sorotan internasional. Pemerintah Pakistan juga melakukan sejumlah terobosan, di antaranya peningkatan bantuan ekonomi multisektoral hingga 1,2 triliun Rupee $(7,4$ miliar Dolar AS), khususnya untuk menggerakkan kembali sektor UMKM yang menjadi tulang punggung ekonomi negara tersebut, tentunya dengan protokol kesehatan ketat. ${ }^{6}$ Di sisi lain, Indonesia disorot secara global akibat masih tingginya kenaikan kasus positif COVID-19. Sejumlah tudingan yang beredar adalah bahwa Pemerintah Indonesia cenderung abai terhadap pandangan ilmiah terkait COVID-19 dan karenanya, penanganan pandemi tersebut menjadi tidak maksimal dan tidak terencana. Ditambah, belakangan Pemerintah Indonesia terkesan terburu-buru dalam menerapkan "kehidupan normal baru" (new normal) yang justru meningkatkan risiko melonjaknya kasus baru. ${ }^{7}$ Dengan demikian, sekuritisasi pandemi oleh Pemerintah Indonesia cenderung tidak efektif.

\section{Kerangka Analisis}

Riset ini akan menggunakan konsep sekuritisasi untuk menjelaskan ancaman COVID-19 terhadap keamanan nasional Pakistan dan Indonesia. Sesuai dengan Mazhab Kopenhagen (Copenhagen School), sekuritisasi di sini dipahami sebagai suatu tindakan untuk mengonstruksi suatu isu keamanan yang sudah memenuhi tiga kriteria retorik dalam tuturan kenegaraan, ${ }^{8}$ yakni (1) klaim bahwa sebuah objek referensi (referent object) berada dalam bahaya eksistensial, (2) tuntutan untuk mengambil kebijakan atau tindakan (countermeasure) untuk menangani ancaman tersebut, dan (3) meyakinkan audiensi bahwa tindakan yang melanggar aturan yang diambil untuk melawan ancaman tersebut dapat dijustifikasi atau justifikasi dilakukannya extraordinary measures atau tindakan luar biasa. Anatomi di sini dimaksudkan sebagai langkah-langkah dan proses yang dilaksanakan oleh aktor pelaksana sekuritisasi, dalam hal ini adalah aktor pemerintah.

Pemahaman ini akan digunakan untuk menjelaskan bagaimana Pemerintah Pakistan dan Indonesia memformulasikan strategi melawan pandemi COVID-19. Pengamatan retorika serta kebijakan terkait akan berfokus kepada beberapa aspek, seperti speech act yang berwujud narasi aparat pemerintah dan peraturan pemerintah, serta hubungan antara aparat sipil dan militer yang merupakan aspek kunci dalam proses sekuritisasi pandemi COVID-19 di kedua negara. Objek referensi dalam sekuritisasi pandemi COVID-19 di kedua negara tentunya adalah keamanan manusia yang meliputi sejumlah sektor, di antaranya kesehatan dan ekonomi, mengingat krisis masif yang ditimbulkan oleh pandemi COVID-19 hingga kini masih terjadi. Anatomi di judul karya ilmiah ini mengacu kepada bagaimana kami akan melihat proses kedua negara tersebut dalam mencoba melakukan sekuritisasi terhadap COVID-19, dan melihat beberapa hal secara lebih dalam baik secara kronologis maupun analitis.

\footnotetext{
${ }^{5}$ Sana Jamal, "COVID-19: Pakistan's Consistent Decline of New Infections Ends with 752 Cases Reported in One Day," 18 September 2020, diakses pada 29 Oktober 2020,

https:/gulfnews.com/world/asia/pakistan/covid-19-pakistans-consistent-decline-of-new-infections-ends-with-752-casesreported-in-one-day-1.73956917.

${ }^{6}$ Mohsin Shafi, Junrong Liu, dan Wenju Ren, "Impact of COVID-19 Pandemic on Micro, Small, and Medium-Sized

Enterprises Operating in Pakistan,” Research in Globalization 2 (Desember 2020): 2-3, https://doi.org/10.1016/j.resglo.2020.100018.

${ }^{7}$ James P. Bean, "Indonesia's 'New Normal' a Disaster in the Making," Asia Times, 11 Juni 2020, diakses pada 30 Oktober 2020, https://asiatimes.com/2020/06/indonesias-new-normal-a-disaster-in-the-making/.

${ }^{8}$ van Munster, R. (n.d.). Securitization. Retrieved from Oxford Bibliographies: https://www.oxfordbibliographies.com/view/document/obo-9780199743292/obo-9780199743292-0091.xml\#obo9780199743292-0091-bibItem-0003.
} 


\section{Analisa}

\section{Anatomi Sekuritisasi Pandemi COVID-19 di Pakistan}

Merujuk pada konsep sekuritisasi dalam pendekatan Copenhagen School, pandemi COVID-19 sendiri telah dinyatakan sebagai ancaman eksistensial di Pakistan sejak kasus pertama terjadi di negara tersebut. Pemerintah Pakistan secara serius menyadari bahwa pandemi yang pertama kali menular secara luas di Republik Rakyat Tiongkok (RRT) ini dapat dengan mudah berjangkit di Pakistan akibat banyaknya warga negara Pakistan yang terkoneksi dengan RRT, adanya perbatasan darat dan kemudahan akses di antara keduanya, dan kedekatan relasi kedua negara secara politik. Apalagi, pada permulaan Februari 2020, jumlah kasus positif COVID-19 di RRT sendiri telah mencapai lebih dari 14.000. ${ }^{9}$ Jumlah penduduk Pakistan yang masif--mencapai lebih dari 200 juta jiwa--juga menjadi faktor bagi tingginya risiko mewabahnya COVID-19 di negara tersebut, ditambah banyaknya lokasi padat penduduk di kawasan urban Pakistan.

Maka, proses sekuritisasi pula dilakukan oleh Pemerintah Pakistan sejak kasus perdana terjadi pada 25 Februari 2020. Kala itu, Zafar Mirza, Staf Perdana Menteri Pakistan untuk urusan kesehatan langsung menyatakan bahwa kasus COVID-19 telah terkonfirmasi di Pakistan. ${ }^{10}$ Selain itu, ia menyatakan bahwa fasilitas kesehatan di Pakistan harus mempersiapkan diri untuk menghadapi pandemi ini, yang berarti bahwa pihak Pemerintah Pakistan telah melakukan speech act yang mengimplikasikan bahwa COVID-19 adalah ancaman keamanan. Selain itu, Dinas Kesehatan Negara Bagian Sindh pada 13 Maret menyatakan pandemi COVID-19 telah terjadi 15 kasus di Sindh sendiri. ${ }^{11}$ Speech act juga dilakukan oleh Presiden Arif Alvi dengan memerintahkan penutupan seluruh akses internasional menuju Pakistan. Presiden juga melarang masyarakat untuk berkerumun, berjabat tangan, serta memerintahkan diterapkannya protokol kesehatan. Meskipun memang, sejatinya sejak 30 Januari 2020, seluruh jalur transportasi yang menghubungkan Pakistan dengan RRT ditutup hingga waktu yang tidak ditentukan.

Pemerintah Pakistan awalnya juga relatif lamban dalam mencegah lonjakan kasus positif COVID-19 ketika pandemi tersebut mulai mewabah. Sosialisasi protokol kesehatan dan perilaku hidup bersih-sehat, penutupan lembaga pendidikan, hingga pembentukan kebijakan darurat sebagai pedoman hidup masyarakat kala pandemi baru benar-benar diimplementasikan pada akhir Maret. ${ }^{12}$ Di antaranya, adalah pembangunan pusat karantina, rumah sakit darurat, dan peningkatan distribusi peralatan medis yang terhambat. Bahkan, perlu berminggu-minggu bagi Pemerintah Pakistan untuk melakukan pemulangan dan penduduk yang bekerja di luar negeri, khususnya RRT dan Iran--dua negara tujuan utama warga Pakistan. Pakistan pula bukanlah negara maju yang memiliki kuantitas kapital yang signifikan untuk menciptakan penanganan yang benar-benar cepat dan komprehensif. Apalagi, anggaran kesehatan di Pakistan sendiri pada permulaan mewabahnya pandemi COVID-19 hanya mencapai 0,75 persen, dengan ketersediaan tempat tidur di seluruh rumah sakit di Pakistan

\footnotetext{
${ }^{9}$ Yawen Chen Lies Elaine, “China Reports Big Rise in Coronavirus Deaths, WHO Sees No 'Tip of Iceberg," Reuters, 14 Februari 2020, diakses pada 29 Oktober 2020, https://www.reuters.com/article/us-china-health-idUSKBN207025.

${ }^{10}$ Mohammad Nafees dan Farukh Khan, "Pakistan's Response to COVID-19 Pandemic and Efficacy of Quarantine and Partial Lockdown: A Review,” Electronic Journal of General Medicine 17, no. 6 (20 April 2020): 240, https://doi.org/10.29333/ejgm/7951.

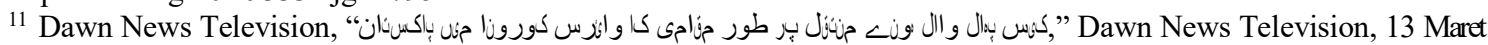
2020, diakses pada 30 Oktober 2020, https://www.dawnnews.tv/news/1122234.

${ }^{12}$ Nafees dan Khan, "Pakistan's Response to COVID-19 Pandemic and Efficacy of Quarantine and Partial Lockdown.", hal. 2-3.
} 
hanya mencapai 0,6 untuk 1.000 penduduk. ${ }^{13}$ Bahkan, pada tahun anggaran 2020-2021, Pemerintah Pakistan hanya menganggarkan 70 miliar Rupee Pakistan untuk penanganan COVID-19, atau secara proporsi, hanya 1,2 persen dari total anggaran belanja Pakistan pada periode yang sama.

Tabel 1. Linimasa Penanganan COVID-19 di Pakistan

\begin{tabular}{|c|c|}
\hline Tindakan & Tanggal Mulai Pelaksanaan dan Keterangan \\
\hline Speech act & $\begin{array}{l}\text { - } 25 \text { Februari } 2020 \text { (Zafar Mirza, Staf PM Pakistan untuk urusan } \\
\text { kesehatan } \\
\text { - } 13 \text { Maret } 2020 \text { (Presiden Arif Alvi) }\end{array}$ \\
\hline $\begin{array}{l}\text { Penutupan akses transportasi } \\
\text { dan pelarangan penerbangan }\end{array}$ & $\begin{array}{l}\text { - } 30 \text { Januari } 2020 \text { (dari dan ke RRT) } \\
\text { - } 23 \text { Februari-2 Maret } 2020 \text { (dari seluruh perbatasan darat) }\end{array}$ \\
\hline $\begin{array}{l}\text { Dimulainya penggalakan uji } \\
\text { COVID-19 }\end{array}$ & $\begin{array}{l}\text { - } 8 \text { Maret } 2020 \text { (uji rapid dan swab pertama kali dilakukan) } \\
\text { - } 28 \text { Maret (uji massal, kedatangan } 50.000 \text { alat uji dari RRT) }\end{array}$ \\
\hline $\begin{array}{l}\text { Dimulainya kunci sementara } \\
\text { (lockdown) }\end{array}$ & $\begin{array}{l}\text { - } 10 \text { Maret } 2020 \text { (total, dimulai di Negara Bagian Sindh) } \\
\text { - } 8 \text { April } 2020 \text { (parsial, sesuai situasi dan kondisi di setiap daerah) }\end{array}$ \\
\hline $\begin{array}{l}\text { Pembangunan pusat-pusat } \\
\text { karantina }\end{array}$ & 14 Maret 2020 (dimulai di Negara Bagian Sindh) \\
\hline $\begin{array}{l}\text { Penetapan kebijakan bantuan } \\
\text { ekonomi }\end{array}$ & $\begin{array}{l}24 \text { Maret 2020, dengan nilai } 1,2 \text { triliun Rupee Pakistan ( } 7,4 \text { miliar Dolar } \\
\text { AS) dengan sasaran usaha kecil dan menengah serta kalangan masyarakat } \\
\text { pekerja. }\end{array}$ \\
\hline
\end{tabular}

Sumber: Pakistan National Command and Operation Center (NCOC), COVID-19 Pakistan

Dari tabel di atas, terlihat bahwa penanganan pandemi COVID-19 di Pakistan relatif lamban, di mana sebagian besar tindakan penanganan baru dilaksanakan pada bulan Maret 2020. Bantuan ekonomi, sebagai salah satu aspek penting dalam mempertahankan sektor-sektor ekonomi Pakistan kala krisis akibat pandemi, menjadi salah satu kebijakan penanganan yang paling akhir diimplementasikan, yakni pada tanggal 24 Maret 2020. Tidak hanya itu, uji COVID-19 baru mulai dilakukan secara massal pada 28 Maret 2020, setelah Pemerintah Pakistan mendatangkan sejumlah besar alat uji dari RRT, dan baru diikuti dengan karantina massal pasien positif COVID-19. Hal ini lantas menjadi penyebab kuat terjadinya lonjakan jumlah penderita COVID-19 di Pakistan pada tiga bulan pertama, yakni mencapai lebih dari 57.000 kasus positif. ${ }^{14}$

Selain terkait lonjakan kasus COVID-19, lambannya mitigasi pandemi COVID-19 oleh Pemerintah Pakistan juga dirasakan masyarakat Pakistan terkait karantina. Ketidaksigapan Pemerintah Pakistan dalam menyediakan fasilitas untuk karantina membuat banyak rumah sakit mengalami kelebihan kapasitas, terutama di kota-kota yang menjadi $h u b$ bagi arus transportasi internasional ke

\footnotetext{
${ }^{13}$ Nadia Noreen dkk., "COVID 19 Pandemic \& Pakistan; Limitations and Gaps,” Global Biosecurity 1, no. 4 (21 Mei 2020): 6-7, https://doi.org/10.31646/gbio.63.

${ }^{14}$ Government of Pakistan, "COVID-19 Live Dashboard - Pakistan,” Google Data Studio, diakses pada 3 November 2020, http://datastudio.google.com/reporting/1PLVi5amcc_R5Gh928gTE8-8r8-fLXJQF/page/R24IB?feature=opengraph.
} 
dan dari Pakistan. ${ }^{15}$ Pada pertengahan Maret 2020 saja, jumlah pemohon karantina di seluruh Pakistan telah melonjak hingga 6.000 orang. Jumlah tersebut didominasi oleh para peziarah yang baru saja pulang dari Iran dan beberapa negara Timur Tengah yang kala itu mengalami lonjakan kasus positif COVID-19. ${ }^{16}$ Dalam sektor lainnya seperti ekonomi, kelambatan ini juga cukup dirasakan, di mana terjadi penghentian operasi pabrik besar-besaran di seluruh Pakistan. Tercatat, dari 2.700 pabrik di Negara Bagian Sindh sendiri, hanya 50 unit yang beroperasi, mengakibatkan lebih dari lima juta pekerja dirumahkan. ${ }^{17}$ Hal yang sama juga terjadi pada sektor UMKM yang berkontribusi hingga 35 persen dari perekonomian Pakistan. Sektor ini membutuhkan interaksi intensif dengan konsumen, sehingga ketika Pemerintah Pakistan menerapkan kebijakan lockdown, sektor ini menjadi salah satu yang paling terdampak. Diperkirakan, terjadi lonjakan penduduk miskin hingga lima juta jiwa di Pakistan. ${ }^{18}$ Parahnya, bantuan ekonomi terhadap masyarakat berpenghasilan menengah ke bawah tersebut baru ditetapkan pada 24 Maret 2020.

Politisasi pandemi COVID-19 menjadi salah satu faktor kunci dalam penanganan pandemi COVID-19 yang lebih strategis dan komprehensif. Politisasi di sini dipahami sebagai bagian dari sekuritisasi, di mana suatu isu--dalam hal ini pandemi COVID-19--yang tengah mengemuka di suatu wilayah diproblematisasi sebagai permasalahan keamanan. Mengingat signifikansi keterlibatan militer dalam urusan publik di Pakistan, maka koordinasi antara sipil dan militer bukanlah suatu hal yang mengejutkan dan justru menjadi salah satu strategi utama dalam konteks ini. Situasi demikian memiliki kaitan dengan sejarah relasi antara sipil dan militer yang cukup panjang di Pakistan. Sejak 1950-an, tepatnya era rezim Presiden Jenderal Ayub Khan (1958-1969), Angkatan Bersenjata Pakistan mulai memegang peranan strategis dalam pemerintahan, namun memiliki aparat pemerintahan yang didominasi sipil. ${ }^{19}$ Berlanjut pada era Presiden Jenderal Muhammad Zia ul Haq (1978-1988), ia menjadi aktor penting dalam pembentukan sistem politik Pakistan modern dengan mengintegrasikan konsep-konsep keislaman dan menjadi suatu identitas politik nasional Pakistan hingga kini. ${ }^{20}$ Jenderal Pervez Musharraf yang lengser pada 2013 menjadi perwira angkatan bersenjata terakhir yang menjadi pemimpin eksekutif di negara tersebut, yakni sebagai perdana menteri.

Dengan kontrol militer atas dinamika politik Pakistan yang cukup signifikan, praktis siapapun tokoh yang memegang tampuk kepemimpinan di negara tersebut harus berkompromi dengan pihak militer, termasuk dalam pengambilan dan pelaksanaan kebijakan. Peran militer dalam dinamika kebijakan di Pakistan dapat dianalisis dalam beberapa pendekatan. Pendekatan pertama, bahwa elite militer berperan dalam eksekusi kebijakan, dengan melibatkan perwira angkatan bersenjata dalam implementasi kebijakan, semisal dengan terlibat dalam mitigasi bencana atau menyosialisasikan undang-undang. ${ }^{21}$ Kedua, militer Pakistan terlibat dalam kontrol kebijakan, di mana banyak elite militer Pakistan yang menjadi penasihat pemerintah, khususnya terkait dengan keamanan nasional.

\footnotetext{
${ }^{15}$ Nafees dan Khan, "Pakistan's Response to COVID-19 Pandemic and Efficacy of Quarantine and Partial Lockdown.”, hal. 3-4.

${ }^{16}$ Nafees dan Khan, hal. 4

${ }^{17}$ Mohsin Shafi, Junrong Liu, dan Wenju Ren, "Impact of COVID-19 Pandemic on Micro, Small, and Medium-Sized Enterprises Operating in Pakistan," hal. 3-4.

${ }^{18}$ Mohsin Shafi, Junrong Liu, dan Wenju Ren, hal. 5

${ }^{19}$ Saeed Shafqat, "Pakistan Military: Sustaining Hegemony and Constructing Democracy?," Journal of South Asian and Middle Eastern Studies 42, no. 2 (2019): 20-51, hal. 25. http://www.jstor.org/stable/10.33428/jsoutasiamiddeas.42.2.0020.

${ }^{20}$ Shafqat, hal. 25-26.

${ }^{21}$ Elisa Ada Giunchi, “The Political and Economic Role of The Pakistani Military,” ISPI, ISPI Analysis, 269 (Juli 2014): 10, hal. 3-4. https://www.ispionline.it/sites/default/files/pubblicazioni/analysis_269_2014.pdf
} 
Singkatnya, stabilitas di Pakistan akan cenderung tercapai bilamana terjadi kohesivitas relasi dan kompromi antara pihak sipil dan militer.

Strategi serupa diterapkan oleh Perdana Menteri Pakistan, Imran Khan, dalam mempolitisasi pagebluk COVID-19, di mana terdapat peran kuat militer di dalamnya. Imran Khan dan jajarannya mengoordinasikan sejumlah lembaga, seperti National Command and Operation Center (NCOC) yang dipimpin oleh Menteri Federal, Asad Umar; National Coordination Committee (NCC), dan National and Provincial Disaster Authorities (NDMA). ${ }^{22}$ Sejak Maret, ketiga institusi tersebut menjadi garda terdepan dalam perencanaan dan implementasi kebijakan dalam penanganan pandemi. Tidak hanya melibatkan aparat sipil, seperti ahli kesehatan dan tenaga medis, sebagai bentuk sinergi antara sipil dan militer, Pemerintah Pakistan juga melibatkan aparat militer dalam koordinasi lembaga-lembaga tersebut, di antaranya (1) pengangkatan seorang letnan jenderal sebagai pemimpin tertinggi NDMA, (2) perlibatan prajurit militer dalam pelaksanaan kebijakan penanganan COVID-19, (3) kontrol kebijakan yang turut melibatkan aparat militer. ${ }^{23}$

Tahapan implementasi atau countermeasure menjadi inti dari proses sekuritisasi pandemi COVID-19. Salah satu langkah Pemerintah Pakistan, adalah pelaksanaan kunci sementara (lockdown). Tidak seperti sejumlah negara lain--Australia, RRT, atau Selandia Baru--yang melakukan kunci sementara total secara kontinu, Pakistan hanya melakukan kunci sementara total pada 10 Maret hingga 8 April $^{24}$, kemudian negara tersebut melakukan kunci sementara yang bersifat parsial hingga waktu makalah ini disusun. Pemerintah Pakistan sendiri menamakan sistem kunci sementara ini sebagai "kunci sementara cerdas" (smart lockdown), di mana aturan tersebut dilaksanakan pada sebagian negara bagian atau wilayah administratif di bawahnya yang mengalami lonjakan kasus positif, tentunya dengan penerapan yang ketat. ${ }^{25}$ Di sisi lain, kawasan yang tidak mengalami lonjakan tidak diberlakukan kunci sementara yang ketat, namun protokol kesehatan tetap selalu dilaksanakan dan durasi aktivitas bisnis dibatasi hingga kasus positif menurun secara kontinu. ${ }^{26}$ Hal ini bertujuan untuk memastikan perekonomian Pakistan tetap berputar dan tidak terjadi hambatan dalam distribusi aneka kebutuhan pokok. Jumlah penduduk Pakistan yang besar dan ketergantungan terhadap sektor ekonomi informal menjadi faktor utama untuk mengantisipasi hambatan tersebut.

Pola keterlibatan aparat militer di dalamnya juga terjadi secara linier dengan relasi sipilmiliter dalam pemerintahan di Pakistan yang sudah terbentuk sejak lama. Alhasil, tindakan luar biasa atau extrordinary action dalam konteks sekuritisasi tidak perlu dilakukan oleh Pemerintah Pakistan, seiring sudah terbentuknya relasi kedua pihak tersebut. Situasi pandemi ini praktis turut mendiversifikasi peran aparat militer di Pakistan dari penjaga keamanan nasional (national security) secara fisik menjadi aparat penjaga keamanan manusia (human security). ${ }^{27}$ Terdapat sejumlah peran pokok dari aparat militer Pakistan dalam penanganan pandemi ini, di antaranya melakukan implementasi kebijakan; semisal melakukan pembangunan fisik fasilitas-fasilitas kesehatan,

\footnotetext{
${ }^{22}$ Hamza Umer dan Muhammad Salar Khan, Evaluating the Effectiveness of Regional Lockdown Policies in the Containment of Covid-19: Evidence from Pakistan, 2020, hal. 6. https://doi.org/10.31219/osf.io/s3fkp, .

${ }^{23}$ Syed Ali Zia Jaffery, "Pakistan's Fight Against COVID-19 Has Made Imran Khan Stronger," 15 September 2020, diakses pada 3 November 2020, https://thediplomat.com/2020/09/pakistans-fight-against-covid-19-has-made-imran-khan-stronger/.

${ }^{24}$ Umer dan Khan, hal. 10.

${ }^{25}$ Ibid., 7-8.

${ }^{26}$ Asad Hashim, “'Smart Lockdown' in Pakistan to Target 500 Coronavirus Hotspots,” 23 Juni 2020, diakses pada 1 November 2020, https://www.aljazeera.com/news/2020/6/23/smart-lockdown-in-pakistan-to-target-500-coronavirus-hotspots. ${ }^{27}$ Pakistan Today Contributor, "Civil, military leadership working jointly against COVID-19: Fawad | Pakistan Today," Pakistan Today, 26 April 2020, diakses pada 30 Oktober 2020, https://www.pakistantoday.com.pk/2020/04/26/civil-militaryleadership-working-jointly-covid-19-fawad/.
} 
menyebarkan peralatan medis ke kawasan-kawasan terpencil di negara bagian semacam Khyber Pakhtunkhwa, Gilgit Baltistan, dan Azad Kashmir, dan melakukan pelayanan kesehatan, mulai dari pelayanan uji COVID-19 dan melakukan pelacakan (tracing) terhadap pasien. ${ }^{28}$ Selain itu, prajurit militer juga berperan penting dalam kontrol terhadap masyarakat agar menaati kebijakan pemerintah, seperti kunci sementara parsial, termasuk di dalamnya pula adalah peran propaganda terhadap publik agar menaati protokol kesehatan. ${ }^{29}$ Praktis, dalam tahapan ini, juga terjadi koordinasi antara aparat militer dan pemerintah negara bagian.

Sejatinya, masih terjadi kekurangan di sana-sini dalam pelaksanaan sekuritisasi COVID-19 di Pakistan. Selain lambannya tindakan penanganan, terjadi pula miskoordinasi antara pemerintah pusat dengan pemerintah negara bagian dalam pelaksanaan lockdown sehingga sejumlah negara bagian cenderung melakukan lockdown secara mandiri, bantuan ekonomi yang salah sasaran, hingga kurangnya kepercayaan sejumlah kalangan terkait upaya penanganan pandemi oleh pemerintah. ${ }^{30}$ Kalangan religius yang banyak terkonsentrasi di madrasah dan pusat peribadahan di penjuru Pakistan menjadi "agen" bagi melonjaknya penularan COVID-19 pada tiga bulan pertama. Apalagi, tercatat bahwa para pemuka agama kurang berkontribusi dalam penerapan protokol kesehatan terhadap para jemaahnya. ${ }^{31}$ Situasi ini menimbulkan pertanyaan terhadap upaya Pemerintah Pakistan membangun kepercayaan terhadap setiap golongan masyarakat secara komprehensif. Tidak hanya itu, tindakan medis terkait COVID-19 juga diwarnai isu menurunnya frekuensi uji COVID-19. Pada periode April hingga Juli, terjadi lonjakan kasus positif di negara tersebut, di mana laman COVID-19 Pemerintah Pakistan mencatat bahwa kenaikan kasus positif tertinggi terjadi pada pertengahan Juni, dengan jumlah mencapai lebih dari 6.800 kasus. $^{32}$ Apabila meninjau demokratisasi dalam penanganan pandemi COVID-19, tindakan Pemerintah Pakistan dengan menjalin relasi dengan pihak militer juga bukan merupakan keputusan yang demokratis, apalagi sebagaimana dijelaskan sebelumnya, militer Pakistan sering kali melakukan intervensi dalam pengambilan kebijakan di negara tersebut. Tetapi, perlu diketahui bahwa secara umum, sekuritisasi memang berada di luar koridor proses politik yang demokratis dan lebih merujuk kepada bagaimana efektivitas aktor pemerintah dalam mengonstruksikan ancaman terhadap audiensi, yakni masyarakat Pakistan sendiri.

Di sisi lain, Pakistan juga telah berprogres dalam menangani pandemi COVID-19 dan perlahan mampu melandaikan kurva kasus positif COVID-19 sejak akhir Juli 2020. Sebanyak 139 pusat karantina di seluruh negara bagian telah dibangun dengan kapasitas lebih dari 35.000 pasien, lengkap dengan tenaga medisnya. ${ }^{33}$ Selain itu, kendati mengalami fluktuasi dalam frekuensi pengujian, kapasitas uji di fasilitas kesehatan di Pakistan meningkat hingga 100.000 pengujian per hari. ${ }^{34} \mathrm{Hal}$ ini menjadi kemajuan tersendiri bagi sektor kesehatan di negara tersebut yang sebelumnya relatif minim dan kekurangan pendanaan. Perkembangan pandemi COVID-19 di Pakistan hingga Oktober dapat dilihat pada grafik di bawah ini.

\footnotetext{
28 "Coronavirus: Youthful Pakistan Appears to Avoid Worst of Pandemic," BBC News, 20 Agustus 2020, diakses pada 6 November 2020, bag. Asia, https://www.bbc.com/news/world-asia-53742214.

${ }^{29}$ Jaffery, "Pakistan's Fight Against COVID-19 Has Made Imran Khan Stronger."

30 “Pakistan's COVID-19 Crisis," Briefing (Karachi: International Crisis Group, 7 Agustus 2020), https://www.crisisgroup.org/asia/south-asia/pakistan/b162-pakistans-covid-19-crisis, hal. 4-9.

${ }^{31}$ Atiqa Khalid dan Sana Ali, "COVID-19 and Its Challenges for the Healthcare System in Pakistan," Asian Bioethics Review (13 Agustus 2020): 5 https://doi.org/10.1007/s41649-020-00139-x, hal. 5.

${ }^{32}$ Government of Pakistan, "COVID-19 Live Dashboard - Pakistan," Google Data Studio, diakses 3 November 2020,

http://datastudio.google.com/reporting/1PLVi5amcc_R5Gh928gTE8-8r8-fLXJQF/page/R24IB?feature=opengraph.

${ }^{33}$ Ibid., 10-11.

${ }^{34}$ Ibid., 12
} 
Gambar 1. Grafik Perkembangan Pandemi COVID-19 di Pakistan

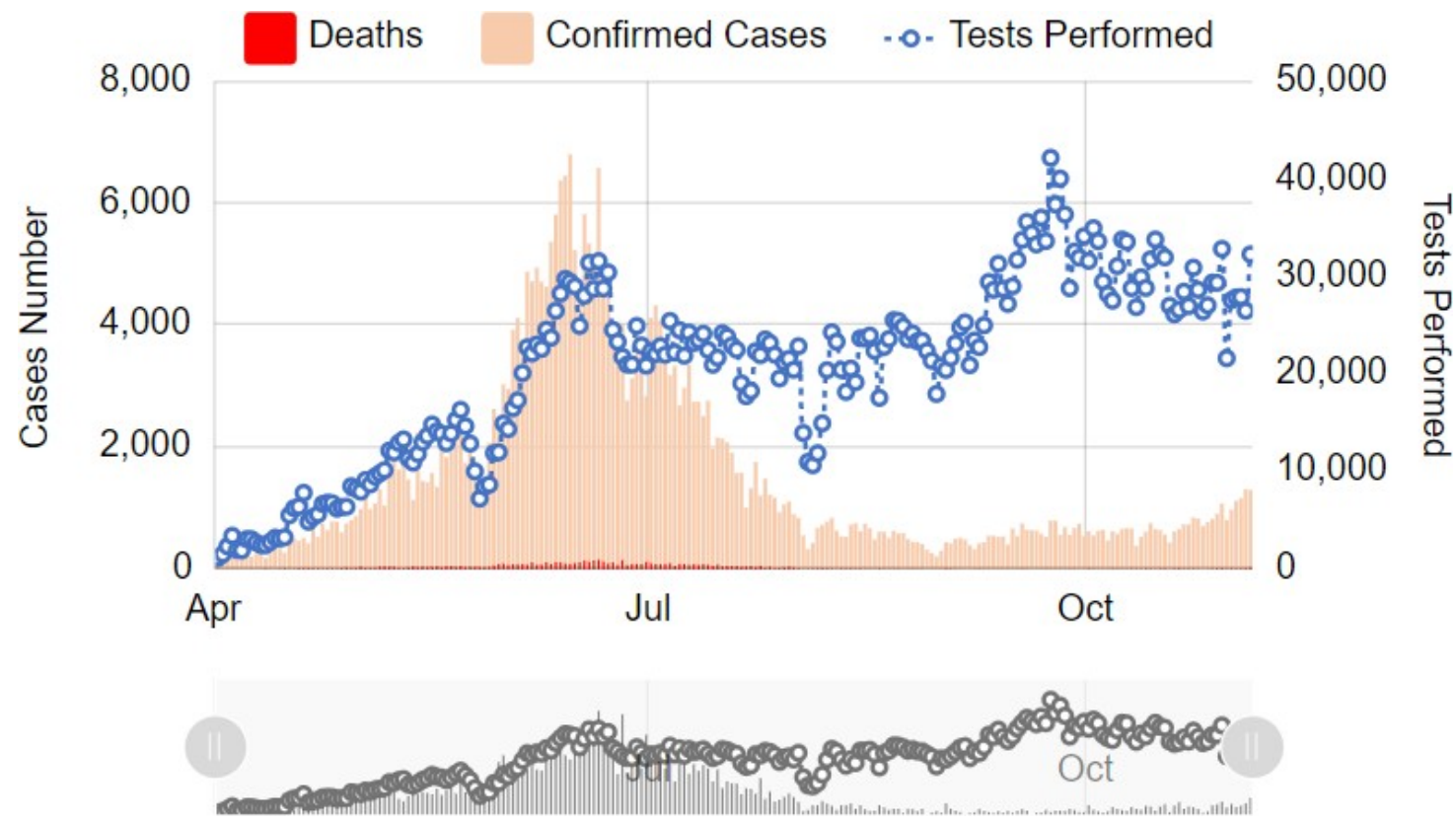

Sumber: COVID-19 Pakistan

Dari grafik yang dikeluarkan oleh laman COVID-19 Pemerintah Pakistan tersebut, tampak bahwa laju peningkatan kasus positif COVID-19 di Pakistan mulai menurun sejak minggu ketiga Juli dan melandai pada bulan Agustus. Kasus positif menurun dari rata-rata 5.000 kasus per hari pada periode Mei-Juni hingga berkisar 1.000 kasus per hari pada awal Agustus. Bahkan, pada 30 Agustus, Pakistan mengalami penularan COVID-19 terendah sepanjang pandemi dengan hanya 213 kasus positif per hari. Penurunan laju penularan tersebut membuat Pakistan disorot secara global, di mana sejumlah media memandang impresif Pakistan dalam penanganan pandemi COVID-19 dibandingkan negara-negara lainnya, khususnya di kawasan Asia Selatan. ${ }^{35}$ Hal ini menunjukkan adanya efektivitas tersendiri dari kebijakan-kebijakan Pemerintah Pakistan, dalam lingkup sekuritisasi pandemi COVID19. ${ }^{36}$ Seiring kurva penularan yang melandai dan laju penularan yang menurun, Pemerintah Pakistan memutuskan untuk membuka kembali institusi pendidikan pada September lalu, namun dapat ditutup kembali sewaktu-waktu terjadi kondisi darurat. ${ }^{37}$ Tidak hanya itu, sektor ekonomi Pakistan juga diharapkan bangkit kembali setelah pemerintah melonggarkan lockdown, khususnya untuk pelaku ekonomi informal seperti pengusaha kecil dan menengah.

Sementara itu, kendati terjadi penurunan jumlah kasus positif, Pemerintah Pakistan mempertimbangkan saran tiga lembaga koordinasi penanganan pandemi--NCOC, NCC, dan NDMA--

\footnotetext{
${ }^{35}$ Niha Dagia, "How Did Pakistan Flatten the Coronavirus Curve?," 24 Agustus 2020, diakses pada 5 November 2020, https://thediplomat.com/2020/08/how-did-pakistan-flatten-the-coronavirus-curve/.

${ }^{36}$ Bremmer, "What Happens Next in Pakistan Now that the Opposition has Come Together," Time, 26 Oktober 2020, diakses pada 4 November 2020, https://time.com/5903364/what-happens-next-in-pakistan-now-that-the-opposition-hascome-together/.

${ }^{37}$ Pakistan Today Contributor, "Schools won't be closed, reiterates education minister | Pakistan Today," Schools won't be closed, reiterates education minister, 3 November 2020, diakses pada 4 November 2020, https://www.pakistantoday.com.pk/2020/11/02/education-minister-address-school-lockdown-rumours/.
} 
untuk tetap mempertahankan situasi tanggap darurat per November $2020 .^{38}$ Hal tersebut dilakukan untuk tetap memantau perkembangan situasi di seluruh negara bagian apabila terjadi lonjakan kasus secara tiba-tiba agar penanganan dapat dilaksanakan secara efektif. Keputusan tersebut dipertegas dengan belum adanya pernyataan verbal dari Perdana Menteri Imran Khan untuk mencabut status tanggap darurat pandemi COVID-19. Praktis, dapat disimpulkan apabila proses desekuritisasi belum dilaksanakan di Pakistan.

\section{Anatomi Sekuritisasi Pandemi COVID-19 di Indonesia}

Dalam kasus Indonesia, sekuritisasi pandemi COVID-19 oleh pemerintah tidak diawali dengan kesadaran akan dampak masif pandemi serta pemahaman bahwa pandemi tersebut harus ditangani secara serius, namun dengan kesan bercanda dan menyepelekan. Hal ini dapat dianggap sebagai kesempatan yang terlewatkan untuk melakukan speech act. Banyak kesempatan komunikasi publik dan sosialisasi yang justru digunakan untuk memberi kesan rendahnya ancaman yang ada dari COVID-19. Kesempatan terlewatkan ini dapat ditemui berulang kali pada periode awal penyebaran virus Korona, seperti Menteri Perhubungan Budi Karya Sumadi yang bercanda bahwa kebalnya orang Indonesia terhadap virus Korona karena "doyan makan nasi kucing", ${ }^{39}$ pernyataan Kepala Badan Koordinasi Penanaman Modal (BKPM) Bahlil Lahadalia tentang sulitnya virus Korona masuk Indonesia akibat perizinan "berbelit-belit" ${ }^{\text {" }}$, dan Menteri Kesehatan Terawan Agus Putranto yang menantang hasil riset Universitas Harvard yang memprediksi kemunculan kasus COVID-19 di Indonesia. ${ }^{41}$ Sikap meremehkan ini juga ditemui bahkan setelah kasus pasien positif COVID-19 telah muncul di Indonesia dan virus Korona ditetapkan WHO sebagai sebuah pandemi, ${ }^{42}$ seperti saat Menko Kemaritiman dan Investasi Luhut Pandjaitan menyatakan bahwa virus Korona lemah di cuaca panas Indonesia; ${ }^{43}$ Ikatan Dokter Indonesia kemudian menyatakan bahwa pernyataan demikian tidak sesuai fakta di lapangan. ${ }^{44}$

Dalam konteks sekuritisasi, Pemerintah Indonesia bahkan masih menginginkan isu ini nonpoliticized atau tidak diperdebatkan secara publik, terutama jika memperhatikan tindakan pemerintah yang justru mencoba untuk memberi kesan bahwa virus Korona mudah ditangani. Hal ini tetap terjadi, meskipun banyak pihak sudah cukup was-was bahkan jauh sebelum kasus pertama COVID-19 muncul di Indonesia. Contohnya, mantan Wakil Presiden Jusuf Kalla ${ }^{45}$ dan anggota

\footnotetext{
${ }^{38} \mathrm{Ibid}$.

${ }^{39}$ Andri Saubani, "Kelakar Menhub: Kita Kebal Corona karena Doyan Nasi Kucing,” Republika, 17 Februari 2020,https://republika.co.id/berita/q5ul4k409/kelakar-menhub-kita-kebal-corona-karena-doyan-nasi-kucing.

${ }^{40}$ Adi Renaldi, "Simak Kompilasi Guyonan Pejabat Indonesia Soal Virus Corona, Agar Harimu Lebih 'Cringe'," VICE, 24 Februari 2020, diakses pada 6 November 2020,

https://www.vice.com/id/article/pkeqag/guyonan-pejabat-indonesia-soal-virus-corona.

${ }^{41}$ CNN Indonesia, "Menkes Tantang Harvard Buktikan Virus Corona di Indonesia," 11 Februari 2020, diakses pada 6 November 2020, https://www.cnnindonesia.com/nasional/20200211195637-20-473740/menkes-tantang-harvard-buktikanvirus-corona-di-indonesia.

${ }^{42}$ DetikNews, "Timeline Setengah Tahun COVID-19 di Indonesia," 2 September 2020, diakses pada 6 November 2020, https://news.detik.com/berita/d-5156199/timeline-setengah-tahun-covid-19-di-indonesia?single=1.

${ }^{43}$ Andri Saubani, "Luhut Sebut Corona Lemah di Cuaca Panas, Ini Kata BMKG,” Republika, 4 April 2020, https://republika.co.id/berita/q891th409/luhut-sebut-corona-lemah-di-cuaca-panas-ini-kata-bmkg.

${ }^{44}$ Muhammad Iqbal, "Virus Corona Lemah di Cuaca Panas? Ini Penjelasan IDI," CNBC Indonesia, 3 April 2020, diakses pada 5 November 2020, https://www.cnbcindonesia.com/news/20200403110351-4-149574/virus-corona-lemah-di-cuacapanas-ini-penjelasan-idi.

${ }^{45}$ Lisye Sri Rahayu, “JK: Indonesia Harus Preventif Hadapi Virus Corona, Urgen Pandemik Ini,” DetikNews, 12 Maret 2020, diakses pada 5 November 2020, https://news.detik.com/berita/d-4935783/jk-indonesia-harus-preventif-hadapi-viruscorona-urgen-pandemik-ini.
} 
Komisi IX DPR RI dari Fraksi PDI-P, Muchamad Nabil Haroen. ${ }^{46}$ Bahkan, Tangguh Chairil menyatakan bahwa pemerintah berupaya mendesekuritisasi isu COVID-19 dengan pernyataanpernyataan yang terkesan meremehkan tersebut; mengarahkan sikap publik agar mengabaikan atau hanya membahas isu COVID-19 secara minim. ${ }^{47} \mathrm{Hal}$ ini tentu cukup berbeda dibandingkan negaranegara lain yang justru sedang mulai "memperkuat tameng" untuk menjaga diri dari dampak pandemi yang lebih signifikan, seperti di Amerika Serikat, ${ }^{48}$ di Singapura, ${ }^{49}$ di Taiwan, ${ }^{50}$ dan juga di Jerman. ${ }^{51}$

Terlepas dari berbagai kesempatan yang terlewatkan dan juga pengakuan Presiden Jokowi yang tidak ingin membeberkan terlalu banyak informasi karena tidak ingin menyebabkan kepanikan, ${ }^{52}$ beberapa waktu setelah jumlah kasus meningkat dan terjadi kematian pertama, ${ }^{53}$ Pemerintah Indonesia baru mencoba untuk menggunakan speech act untuk mengonstruksikan bahwa virus Korona adalah ancaman eksistensial. Proses sekuritisasi baru benar-benar dimulai dengan adanya Keputusan Presiden (Keppres) Nomor 7 Tahun 2020 yang membentuk Gugus Tugas Percepatan Penanganan COVID-19 dengan Letnan Jenderal Doni Monardo sebagai ketuanya pada 13 Maret 2020. Pada 31 Maret, Presiden Joko Widodo mengeluarkan Keputusan Presiden (Keppres) Nomor 11 Tahun 2020 yang menetapkan pandemi COVID-19 sebagai darurat kesehatan masyarakat. ${ }^{54}$ Padahal, pada saat yang sama, pandemi telah mewabah ke seluruh provinsi di Indonesia dengan kasus positif mencapai 3.500. Dapat diargumentasikan bahwa peningkatan kasus positif COVID-19 menjadi sebuah ancaman keamanan negara--baik dari segi kesehatan maupun ekonomi--sudah lebih terbentuk dan konsisten digabungkan melalui berbagai regulasi tersebut. ${ }^{55}$

Tabel 2. Pernyataan Pemerintah Indonesia yang Meremehkan Isu COVID-19, Hingga Februari 2020

\begin{tabular}{|c|l|l|}
\hline \multicolumn{1}{|c|}{ Tanggal } & \multicolumn{1}{|c|}{ Pejabat Pemerintah } & \multicolumn{1}{c|}{ Pernyataan } \\
\hline 27 Januari 2020 & Menkes Terawan Agus Putranto & $\begin{array}{l}\text { Pencegahan virus Korona adalah dengan } \\
\text { tidak panik dan resah, "enjoy” saja, dan } \\
\text { makan secukupnya. }\end{array}$ \\
\hline
\end{tabular}

\footnotetext{
${ }^{46}$ Hiski Darmayana, "Kemenkes Harus Sampaikah Langkah-langkah Preventif," Gesuri.id, 3 Maret 2020, diakses pada 7 November 2020, https://www.gesuri.id/pemerintahan/kemenkes-harus-sampaikan-langkah-langkah-preventif-b1YI5ZrA5. ${ }^{47}$ Tangguh Chairil, "RESPONS PEMERINTAH INDONESIA TERHADAP PANDEMI COVID-19: DESEKURITISASI DI AWAL, SEKURITISASI YANG TERHAMBAT,” IR Binus, 23 Maret 2020, diakses pada 4 November 2020, https://ir.binus.ac.id/2020/03/23/respons-pemerintah-indonesia-terhadap-pandemi-covid-19-desekuritisasi-di-awalsekuritisasi-yang-terhambat/.

${ }^{48}$ BBC News, "Coronavirus: What measures are countries taking to stop it?," BBC News, 1 April 2020, diakses pada 27 Maret 2021, https://www.bbc.com/news/world-51737226.

${ }^{49}$ Toh Ting Wei \& Salma Khalik, "Covid-19: S'pore rolls out more measures including limiting, where possible, size of gatherings to 250 people; workplace distancing,” Strait Times, 13 Maret 2020, diakses 26 Maret 2020,

https://www.straitstimes.com/singapore/health/covid-19-singapore-rolls-out-more-measures-including-limiting-wherepossible-the.

${ }^{50}$ Cindy Sui, "What Taiwan can teach the world on fighting the coronavirus," NBC News, 10 Maret 2020, diakses pada 25 Maret 2020, https://www.nbcnews.com/health/health-news/what-taiwan-can-teach-world-fighting-coronavirus-n1153826.

${ }^{51}$ Erbil Basay, "Germany: COVID-19 measures in place until April 20," Anadolu Agency, 28 Maret 2020, diakses 26 Maret 2020, https://www.aa.com.tr/en/europe/germany-covid-19-measures-in-place-until-april-20/1783203.

${ }^{52}$ Andhika Prasetia, “Jokowi Tak Ingin Warga Panik soal Corona: Pemerintah Bekerja, Tak Bersuara,” Detik News, 13 Maret 2020, diakses pada 5 November 2020, https://news.detik.com/berita/d-4937698/jokowi-tak-ingin-warga-panik-soalcorona-pemerintah-bekerja-tak-bersuara.

${ }^{53}$ DetikNews, "Timeline Setengah Tahun COVID-19 di Indonesia," 2 September 2020, diakses pada 4 November 2020, https://news.detik.com/berita/d-5156199/timeline-setengah-tahun-covid-19-di-indonesia?single=1.

${ }^{54} \mathrm{Ibid}$.

${ }^{55}$ Rage Taufika, "Latent Securitisation of Illegal, Unreported, and Unregulated (IUU) Fishing in Indonesia," Global: Jurnal Politik Internasional, 22 (1): 34, doi: 10.7454/global.v22i1.488.
} 


\begin{tabular}{|c|c|c|}
\hline 7 Februari 2020 & Menko Polhukam Mahfud MD & $\begin{array}{l}\text { Indonesia adalah satu-satunya negara besar } \\
\text { di Asia yang belum memiliki kasus positif } \\
\text { virus Korona. }\end{array}$ \\
\hline 11 Februari 2020 & Menkes Terawan Agus Putranto & $\begin{array}{l}\text { Mendiskreditkan penelitian Harvard T.H. } \\
\text { Chan School of Public Health yang } \\
\text { menyimpulkan bahwa virus Korona } \\
\text { seharusnya sudah ada di Indonesia namun } \\
\text { tidak terdeteksi. }\end{array}$ \\
\hline 15 Februari 2020 & $\begin{array}{l}\text { Menko Perekonomian Airlangga } \\
\text { Hartarto, dikutip oleh Menko } \\
\text { Polhukam Mahfud MD }\end{array}$ & $\begin{array}{l}\text { Virus Korona tidak dapat masuk Indonesia } \\
\text { karena perizinan berbelit-belit. }\end{array}$ \\
\hline 17 Februari 2020 & Menhub Budi Karya Sumadi & $\begin{array}{l}\text { Bercanda bahwa tidak ada virus Korona di } \\
\text { Indonesia karena masyarakat kebal karena } \\
\text { suka makan nasi kucing. }\end{array}$ \\
\hline 24 Februari 2020 & $\begin{array}{l}\text { Sekretaris Ditjen P2P Kemenkes } \\
\text { Achmad Yurianto }\end{array}$ & $\begin{array}{l}\text { Ia bersikeras bahwa SARS-CoV-2 berbeda } \\
\text { dari COVID-19 padahal COVID-19 adalah } \\
\text { nama penyakitnya, sementara virus yang } \\
\text { menyebabkannya dinamai SARS-CoV-2 } \\
\text { oleh Komite Internasional Taksonomi Virus } \\
\text { (ICTV). }\end{array}$ \\
\hline 26 Februari 2020 & Wapres Ma'ruf Amin & $\begin{array}{l}\text { Virus Korona tidak berani datang ke } \\
\text { Indonesia karena doa kunut ulama dan } \\
\text { istigasah. }\end{array}$ \\
\hline 29 Februari 2020 & $\begin{array}{l}\text { Staf Ahli Utama KSP Ali Mochtar } \\
\text { Ngabalin }\end{array}$ & $\begin{array}{l}\text { Tidak ada virus Korona di Indonesia karena } \\
\text { virus tersebut tidak berkembang kuat di } \\
\text { negara tropis. }\end{array}$ \\
\hline
\end{tabular}

Sumber: Tangguh Chairil, "Respons Pemerintah Indonesia Terhadap Pandemi Covid-19: Desekuritisasi di Awal, Sekuritisasi yang Terhambat” IR Binus, 23 Maret 2020

Terdapat dua kebijakan terkait penanganan pandemi Pemerintah Indonesia yang akan dikritik dari perspektif sekuritisasi, yakni (1) Proyek Lumbung Pangan atau Food Estate, dan (2) Instruksi Presiden (Inpres) Nomor 6 Tahun 2020. Riset ini menemukan bahwa proses sekuritisasi gagal karena tidak berhasil memenuhi kriteria speech act yang sesuai. Perlu diingat bahwa gagal dan suksesnya sekuritisasi bukan didasari oleh standar normatif tertentu, namun didasari oleh resistensi masyarakat yang mengakibatkan diskusi publik mengalahkan kebijakan-kebijakan sekuritisasi. Hal ini dikarenakan sekuritisasi yang memang pada dasarnya bergerak di luar koridor yang demokratis, dengan diperlukannya peran pemerintah untuk meyakinkan audiensi akan perlunya rule-breaking behavior atau perilaku yang melanggar hukum guna melawan ancaman keamanan.

Isu pertama, adalah Proyek Lumbung Pangan atau Food Estate. Presiden Jokowi mencoba membuat ketahanan pangan dan ketersediaan pangan rakyat sebagai referent object dan disrupsi 
pandemi COVID-19 terhadap sektor pangan dunia menjadi existential threat ${ }^{56}$ Presiden menjelaskan pada 9 Juli 2020 bahwa FAO telah mengeluarkan peringatan bahwa krisis pangan akan melanda dunia karena pandemi, juga karena memang adanya musim yang tidak bisa diatur dan diprediksi, sehingga cadangan pangan strategis perlu dibentuk. ${ }^{57}$ Jokowi menempatkan Menteri Pertahanan Prabowo Subianto sebagai pihak yang memimpin proyek ini, dengan menyatakan bahwa karena menyangkut cadangan strategis pangan nasional, tanggung jawab pengelolaan food estate akan diberikan kepada menteri pertahanan dan didukung oleh menteri pertanian dan menteri pekerjaan umum. Tentu terlihat adanya extraordinary measures yang dilakukan oleh pemerintahan Presiden Jokowi, dengan justru menunjuk menteri pertahanan untuk menangani proyek lumbung pangan, alih-alih menteri pertanian. Pada tanggal 13 Juli, Presiden Jokowi menambahkan argumennya dengan menyatakan bahwa pertahanan itu bukan hanya urusan alutsista, tetapi juga ketahanan dalam bidang pangan. Ini menunjukkan securitizing act yang berusaha untuk menjustifikasi memimpinnya kementerian pertahanan dan bukan menteri pertanian untuk pegembangan food estate. ${ }^{58}$ Pernyataan ini mengandung unsur extraordinary measures, di mana suatu lembaga yang melakukan kegiatan yang di luar kegiatan biasanya yakni menteri pertahanan ditunjuk untuk memimpin proyek yang semestinya menjadi pekerjaan menteri pertanian. ${ }^{59}$

Memang secara teoritis dan komparatif, ketahanan pangan dapat memporak-porandakan suatu negara. Sebagai contoh, Mesir adalah negara yang pernah terkena dampak masif dalam situasi ini, mengingat Musim Semi Arab juga dipengaruhi akibat frustrasinya rakyat Mesir terhadap minimnya ketahanan pangan negara mereka dan ketergantungan akut Mesir terhadap pasokan pangan dari luar negeri. ${ }^{60}$ Jika persediaan pangan Mesir dibantu dengan adanya food estate, kekacauan yang terjadi bisa diminimalisir atau bahkan dihindari sama sekali. ${ }^{61}$ Ide lumbung pangan ini sebenarnya telah dilaksanakan di Indonesia pada 1995, namun hasilnya kurang memuaskan, di mana program tersebut mandeg dan berakhir dengan kerusakan lingkungan serta dugaan korupsi. ${ }^{62}$ Ketahanan dan swasembada pangan yang diklaim pada zaman Orde Baru pula sejatinya tercapai karena adanya tekanan luar biasa pada para petani untuk menanam padi melalui upaya-upaya represif institusi militer. ${ }^{63}$ Ketidakyakinan lain yang muncul adalah pandangan sejumlah anggota legislatif yang meragukan prospek kesuksesan program ini. Sejatinya secara pelaksanaan, program lumbung pangan ini masih berjalan dan resistensi publik terhadap sekuritisasi ini nampaknya tidak begitu berdampak, sehingga tidak menunda atau membatalkan pelaksanaan program ini. Namun, terlihat bahwa relasi antara kebijakan lumbung pangan-militer-pandemi sudah masuk dalam diskusi publik dan aspek

\footnotetext{
${ }^{56}$ Egi Adyatama, “Jokowi Buka Alasan Tunjuk Prabowo Pimpin Proyek Lumbung Pangan,” Tempo.co, 13 Juli 2020, https://nasional.tempo.co/read/1364810/jokowi-buka-alasan-tunjuk-prabowo-pimpin-proyek-lumbungpangan/full\&view $=$ ok.

${ }^{57}$ Antara, "Jokowi Tunjuk Prabowo Jadi Leading Sector Lumbung Pangan Baru,” Tempo.co, 9 Juli 2020, https://bisnis.tempo.co/read/1363324/jokowi-tunjuk-prabowo-jadi-leading-sector-lumbung-pangan-baru/full\&view=ok ${ }^{58}$ Egi Adyatama, "Jokowi Buka Alasan."

${ }^{59}$ Floyd (2015) di M. Rizqi Isnurhadi, "Sekuritisasi Illegal, Unreported, Unregulated Fishing (IUUF) di Perairan Indonesia di Era Pemerintahan Joko Widodo," Jurnal Ilmu Hubungan Internasional, X(2), Juli-Desember 2017, hal. 125.

${ }^{60}$ Alfin Febrian Basundoro \& Fadhil Haedar Sulaeman, "MENINJAU PENGEMBANGAN FOOD ESTATE SEBAGAI STRATEGI KETAHANAN NASIONAL PADA ERA PANDEMI COVID-19,” Jurnal Kajian Lemhanas, 8(2): 36, 2020. ${ }^{61}$ Ibid., 37.

${ }^{62}$ Lisa Siregar, wawancara dengan Arif Zulkifli, Apa Kata Tempo, Eps. 40: "Acakadut Program Lumbung Pangan di Lahan Gambut," audio podcast, 13 Agustus 2020, https://open.spotify.com/episode/342IkMHfGOKR9aX5SWvCJ8?si=NPh4UzKzSK6a0smGvd8iJg.

${ }^{63}$ CNN Indonesia, "Kemenhan Pimpin Lumbung Pangan: Memori Orde Baru di Isu OMSP," 13 Juli 2020, diakses pada 6 November 2020, https://www.cnnindonesia.com/nasional/20200713093910-20-523889/kemenhan-pimpin-lumbung-panganmemori-Orde Baru-dan-isu-omsp.
} 
retorika speech act dalam kasus ini belum dapat meyakinkan publik sepenuhnya akan diperlukannya extraordinary measures tersebut.

Kasus kedua yang menjadi perhatian, yakni implementasi Inpres Nomor 6 Tahun 2020. Peraturan yang ditandatangani pada tanggal 4 Agustus 2020 ini berisi instruksi Presiden untuk melibatkan TNI dalam penegakan peraturan protokol kesehatan selama pandemi. Hal ini dilakukan dengan tujuan untuk membantu pelaksanaan dan juga pengenaan sanksi terhadap pelanggaran protokol di tengah masyarakat. Hal ini merupakan extraordinary measures dalam konteks memberikan suatu kekuasaan darurat tertentu ke suatu instansi. ${ }^{64}$ Hal yang menarik adalah speech act yang diberikan oleh Menteri Koordinator Politik Hukum dan Keamanan Mahfud MD, di mana ia menjelaskan bahwa pelibatan TNI dilakukan karena Indonesia mempunyai konsepsi hankamrata, yakni pertahanan dan keamanan rakyat semesta. ${ }^{65}$ Tentu logika doktrinal ini cukup ambigu dan terlalu luas, sampai bisa dimasukkan dalam hampir segala isu terkait keamanan nasional. Namun yang perlu digaris bawahi sebagai salah satu faktor kegagalan adalah bagaimana pemerintah tidak spesifik dalam mengeluarkan aturan tersebut untuk tetap mempertahankan dan meyakinkan publik tentang tetap akan adanya supremasi sipil; sesuatu yang tentunya menjadi salah satu tuntutan reformasi Indonesia yakni pencabutan dwifungsi TNI-Polri yang menuntut dijauhkannya aparat militer atau kepolisian dari ranah sipil. ${ }^{66}$ Melalui Inpres ini, jargon "ABRI Masuk Desa” zaman Orde Baru dapat terulang dan justru akan mengurangi keyakinan masyarakat terhadap pemerintahan Jokowi yang dipandang bergantung secara berlebihan terhadap institusi militer, terlebih, karena Inpres ini dikeluarkan setelah program lumbung pangan dimulai ${ }^{67}$ Pemerintah yang awalnya memandang masyarakat sebagai audiensi yang perlu diberikan pemahaman agar penanganan pandemi berjalan lancar, malah semakin menganggap mereka sebagai pihak yang harus didisiplinkan dengan tindakan militer. Pendeknya, pemerintah melakukan alienasi publik dengan melakukan sekuritisasi tersebut.

Hingga makalah ini ditulis, Indonesia sedang mengalami resesi ekonomi yang tentu saja merupakan salah satu dampak masif dari pandemi COVID-19. ${ }^{68}$ Pada Oktober 2020, Indonesia kembali menjadi negara dengan kasus tertinggi di area Asia Tenggara ${ }^{69}$ dan keempat tertinggi di Asia dengan jumlah kasus positif mencapai lebih dari $420.000 .^{70}$ Penanganan Indonesia terhadap pandemi pun disorot oleh Direktur Jenderal WHO, Tedros Adhanom Ghebreyesus yang hendak memanggil menteri Terawan untuk berbincang mengenai proses tinjauan mereka, yakni Intra-Action-Review atau IAR. Hal ini dipandang oleh epidemiolog dari Universitas Indonesia, Pandu Riono, sebagai upaya WHO untuk mengevaluasi Indonesia terkait hal-hal yang selama ini kurang maksimal dilakukan,

\footnotetext{
${ }^{64}$ Floyd (2015) di M. Rizqi Isnurhadi, "Sekuritisasi Illegal, Unreported, Unregulated Fishing (IUUF) di Perairan Indonesia di Era Pemerintahan Joko Widodo,” Jurnal Ilmu Hubungan Internasional, X(2), Juli-Desember 2017, hal. 125.

${ }^{65}$ Mohammad Bernie, "Dwi Fungsi Saat Pandemi: Jokowi Melibatkan TNI untuk Tangani Corona," Tirto.id, 13 Agustus 2020, https://tirto.id/dwi-fungsi-saat-pandemi-jokowi-melibatkan-tni-untuk-tangani-corona-fXcx.

${ }^{66}$ Erik Prasetya, "Hari-hari jelang Reformasi, 20 tahun lalu, dalam gambar dan catatan,” BBC, 21 Mei 2018, diakses pada 6 November 2020,

https://www.bbc.com/indonesia/indonesia-44192970.

${ }^{67}$ Haris Prabowo, "Prabowo Subianto, Menhan ‘Rasa' Mentan yang Urusi Lumbung Pangan,” Tirto.id, 15 Juli 2020, diakses pada 6 November 2020, https://tirto.id/prabowo-subianto-menhan-rasa-mentan-yang-urusi-lumbung-pangan-fQVc.

${ }^{68}$ Chandra Gian Asmara, "Indonesia Resmi Resesi, Ini Buktinya 'Perihnya' di Masyarakat," CNBC Indonesia, 7 November 2020, diakses pada 8 November 2020, https://www.cnbcindonesia.com/news/20201107082302-4-200008/indonesia-resmiresesi-ini-buktinya-perihnya-di-masyarakat.

${ }^{69}$ CNN Indonesia, "Kasus Covid-19 Indonesia Kembali Tertinggi di Asia Tenggara," 15 Oktober 2020, diakses pada 6 November 2020, https://www.cnnindonesia.com/internasional/20201015194430-106-558963/kasus-covid-19-indonesiakembali-tertinggi-di-asia-tenggara.

${ }^{70}$ Ayunda Septiani, "Daftar 5 Negara dengan Kasus COVID-19 Tertinggi di Asia, Indonesia Urutan 4," DetikHealth, 6 November 2020, diakses pada 7 November 2020, https://health.detik.com/berita-detikhealth/d-5243656/daftar-5-negaradengan-kasus-covid-19-tertinggi-di-asia-indonesia-urutan-4.
} 
dengan harapan adanya perbaikan dalam penanganan pandemi. ${ }^{71}$ Melihat beberapa hal tersebut, agaknya Indonesia masih memiliki banyak pekerjaan rumah dalam hal menangani pandemi dan juga perlu beberapa perbaikan agar sekuritisasinya dapat berjalan efektif dan terencana dengan baik. Kurang suksesnya sekuritisasi Indonesia bukan dalam hal kesuksesan kebijakan, namun dalam hal meyakinkan publik mengenai retorika para pemangku kebijakan; sesuatu yang kami rasa dapat dilihat dari penggunaan retorika dan kebijakan lama dalam proyek Food Estate dan alienasi terhadap publik menggunakan Inpres Nomor 6 Tahun 2020.

\section{Membandingkan Pakistan dan Indonesia}

Secara garis besar, kedua negara sama-sama menemui serangkaian masalah dalam menangani pandemi. Namun, perlu diingat bahwa kedua negara ini memiliki pandangan yang cukup berbeda dalam konteks relasi sipil-militer. Seperti yang telah dijelaskan sebelumnya, Pakistan memiliki koordinasi strategis antara pihak sipil yang dikepalai Imran Khan dan pihak militer Pakistan. Hal ini berkorelasi dengan cukup suksesnya pelaksanaan protokol anti pandemi di negara tersebut. Selain itu, perlu dipahami pula bahwa dari segi retorika speech act, Pakistan secara alami lebih mampu meyakinkan publik terkait kerja samanya dengan pihak militer dalam penanganan pandemi karena sejarah relasi militer-sipil yang memang panjang, apalagi menyangkut peran militer dalam pengambilan kebijakan di negara tersebut. Hal ini tentu berbeda dengan Indonesia yang telah mengalami transisi demokrasi melalui Reformasi 1998 yang membawa beberapa tuntutan, salah satunya adalah pencabutan dwifungsi TNI-Polri. Dari tuntutan tersebut, tentu visi publik Indonesia bergeser dari pemerintahan yang militeristik di bawah Presiden Soeharto ke pemerintahan yang memiliki visi demokratis dan supremasi sipil yang lebih kokoh. Akibatnya, penempatan tokoh-tokoh militer ke dalam ranah sipil sering kali terkesan tabu dan kontroversial, walaupun praktik demikian hingga kini masih terjadi.

Terkait konteks sekuritisasi kedua negara, Mazhab Kopenhagen melihat bahwa rule-breaking behavior yang berada di luar koridor demokrasi adalah hal yang lazim dilakukan oleh negara. Namun, Mazhab Kopenhagen memandang bahwa desekuritisasi adalah sesuatu yang harus diupayakan untuk diraih agar sekuritisasi tidak terlalu lama mengganggu proses demokrasi. Dengan adanya bukti bahwa Pakistan cukup efektif dalam menangani pandemi dibandingkan Indonesia, dapat dinyatakan bahwa kepercayaan masyarakat dan kedekatan sipil-militer memiliki korelasi yang menarik untuk diselidiki. Akan tetapi, dalam konteks Pakistan, adanya kepercayaan masyarakat terhadap pihak militer menyebabkan desekuritisasi akan lebih mungkin dilakukan karena pragmatisme, ketimbang untuk menaati tuntutan demokratisasi. Hal ini berbeda dengan Indonesia yang memiliki masyarakat yang cenderung berpersepsi negatif terhadap meluasnya pengaruh militer ke dalam ranah sipil, sehingga menuntut perlunya komunikasi krisis yang lebih baik. ${ }^{72}$ Terlebih karena agenda demokratisasi dan supremasi sipil yang lebih kental di Indonesia dibandingkan di Pakistan.

\footnotetext{
${ }^{71}$ Kumparan, "Ahli Wabah UI: Kemenkes Salah Baca Undangan WHO, RI Belum Sukses Tangani Corona," 6 November 2020, diakses pada 7 November 2020, https://kumparan.com/kumparannews/ahli-wabah-ui-kemenkes-salah-baca-undanganwho-ri-belum-sukses-tangani-corona-1uX21NTW9KL/full.

${ }^{72}$ Remotivi, "Belajar dari Komunikasi Pemerintah: Menghadapi Pandemi Tanpa Empati," YouTube video, 8:10, 29 April 2020, https://www.youtube.com/watch?v=8EFv2kv_s8o
} 


\section{Kesimpulan}

Sekuritisasi yang dilakukan Pemerintah Pakistan dan Indonesia mengonstruksikan pandemi COVID-19 sebagai ancaman eksistensial bagi aspek keamanan manusia di kedua negara, sekaligus aneka sektor strategis lainnya. Sejalan dengan konsep dasar Copenhagen School, kedua pemerintah memiliki anatomi sekuritisasi yang serupa, namun memiliki perbedaan langkah dan hasil sekuritisasi yang signifikan. Pakistan misalnya, sejak awal telah melakukan langkah-langkah yang linier dengan skema sekuritisasi, diawali dengan speech act oleh sejumlah petinggi negara secara serius, sehingga bahaya dari pandemi COVID-19 dapat disadari oleh seluruh penduduk. Selain itu, Pemerintah Pakistan juga mampu membangun relasi sipil-militer yang kohesif dan strategis, menjadi faktor penting dalam efektivitas sekuritisasinya. Meski lamban dalam melakukan tahapan sekuritisasi berikutnya--politisasi dan pelaksanaan kebijakan (countermeasure), namun Pakistan secara bertahap mampu melakukan penanganan secara komprehensif, bahkan mampu menurunkan kurva positif COVID-19.

Di sisi lain, sekalipun Indonesia juga melakukan proses sekuritisasi, namun prosesnya kurang sistematis dan diwarnai ketidakseriusan penanganan pandemi. Diawali dengan ketidakmampuan Pemerintah Indonesia memanfaatkan momentum untuk melaksanakan speech act guna memberikan kesadaran akan bahaya pandemi atau sosialisasi secara komprehensif, pelaksanaan kebijakan yang cenderung nyeleneh juga menjadi sorotan global akibat aneka miskonsepsi terkait pandemi yang justru digabungkan oleh pemerintah Indonesia sendiri. Alhasil, tampak bahwa sekalipun juga banyak mengalami kekurangan dan mendapat kritikan, sekuritisasi COVID-19 Pakistan lebih efektif dibandingkan Indonesia, dan secara bertahap mampu mengendalikan pandemi, ditandai dengan berkurangnya laju kenaikan kasus positif COVID-19 di negara tersebut.

Diskusi terkait sekuritisasi pandemi COVID-19 di negara berkembang juga tidak lantas merujuk pada seberapa demokratis proses sekuritisasi tersebut, seiring dengan besarnya peranan aktor pemerintah dalam mengkonstruksikan ancaman pandemi. Diskusi terkait sekuritisasi pandemi COVID-19 akan lebih relevan apabila dipandang menggunakan analisis efektivitas, alih-alih demokrasi. Copenhagen School sebagai paradigma utama yang menjelaskan soal sekuritisasi pun menganggap bahwa sekuritisasi sendiri juga berbahaya terhadap demokratisasi, sejalan dengan asumsi di atas. Dalam konteks Pakistan dan Indonesia misalnya, pelaksanaan sekuritisasi pandemi COVID-19 justru lebih efektif dilakukan oleh pemerintahan yang tidak demokratis, peran aktor sipil yang buruk, dan kerap diintervensi oleh pihak militer layaknya Pakistan dibandingkan dengan Indonesia yang secara umum lebih demokratis dan memiliki ruang politik yang lebih terbuka.

Selain itu, terdapat korelasi antara demokratisasi yang lebih rendah dengan efektivitas sekuritisasi pandemi COVID-19, dengan minimnya konflik kepentingan dan kecenderungan kontrol yang lebih kuat dari pemerintah terhadap masyarakat agar menaati kebijakan countermeasure, namun dengan catatan bahwa sedari awal, speech act dilakukan dengan orientasi yang serius dan secara komprehensif meyakinkan masyarakat. Alhasil, pekerjaan rumah yang perlu diperhatikan Indonesia adalah desekuritisasi dan komunikasi krisis.

Di sisi lain, karena kepercayaan mereka yang mendalam kepada aparat militer ditambah adanya koordinasi pemerintahan sipil dan militer dalam penanganan pandemi, masyarakat Pakistan agaknya tidak mempermasalahkan bagaimana campur tangan militer dalam pemerintahan sipilnya terkait pandemi, sebuah sentimen yang tidak terjadi dalam konteks dinamika sosial-politik di Indonesia. 


\section{Daftar Pustaka}

Adi Renaldi, "Simak Kompilasi Guyonan Pejabat Indonesia Soal Virus Corona, Agar Harimu Lebih 'Cringe'," VICE, 24 Februari 2020, diakses pada 6 November 2020,

Alfin Febrian Basundoro \& Fadhil Haedar Sulaeman, "MENINJAU PENGEMBANGAN FOOD ESTATE SEBAGAI STRATEGI KETAHANAN NASIONAL PADA ERAPANDEMI COVID-19,” Jurnal Kajian Lemhanas, 8(2): 36, 2020.

Andhika Prasetia, "Jokowi Tak Ingin Warga Panik soal Corona: Pemerintah Bekerja, Tak Bersuara," Detik News, 13 Maret 2020, diakses pada 5 November 2020, https://news.detik.com/berita/d4937698/jokowi-tak-ingin-warga-panik-soal-corona-pemerintah-bekerja-tak-bersuara.

Andri Saubani, "Kelakar Menhub: Kita Kebal Corona karena Doyan Nasi Kucing," Republika, 17 Februari2020, https://republika.co.id/berita/q5ul4k409/kelakar-menhub-kita-kebal-corona-karena-doyannasi-kucing.

Andri Saubani, "Luhut Sebut Corona Lemah di Cuaca Panas, Ini Kata BMKG," Republika, 4 April 2020, https://republika.co.id/berita/q891th409/luhut-sebut-corona-lemah-di-cuaca-panas-inikata-bmkg.

Anggraeni, Yulia, Lia Maulia Indrayani, dan Ypsi Soeria Soemantri. "The Expressive Speech Act on Ridwan Kamil's Comments in Instagram Posting about First COVID-19 Case in Indonesia." Journal of English Education and Teaching 4, no. 3 (2 September 2020): 368-85. https://doi.org/10.33369/jeet.4.3.368-385.

Antara, “Jokowi Tunjuk Prabowo Jadi Leading Sector Lumbung Pangan Baru,” Tempo.co, 9 Juli 2020, https://bisnis.tempo.co/read/1363324/jokowi-tunjuk-prabowo-jadi-leading-sectorlumbung-pangan-baru/full\&view $=\mathrm{ok}$

Ayunda Septiani, "Daftar 5 Negara dengan Kasus COVID-19 Tertinggi di Asia, Indonesia Urutan 4," DetikHealth, 6 November 2020, diakses pada 7 November 2020, https://health.detik.com/berita-detikhealth/d-5243656/daftar-5-negara-dengan-kasus-covid-19tertinggi-di-asia-indonesia-urutan-4.

Bean, James P. “Indonesia's 'New Normal' a Disaster in the Making.” Asia Times, 11 Juni 2020. https://asiatimes.com/2020/06/indonesias-new-normal-a-disaster-in-the-making/.

Bremmer. "What Happens Next in Pakistan Now that the Opposition has Come Together." Time, 26 Oktober 2020. https://time.com/5903364/what-happens-next-in-pakistan-now-that-theopposition-has-come-together/.

Chandra Gian Asmara, "Indonesia Resmi Resesi, Ini Buktinya 'Perihnya' di Masyarakat," CNBC Indonesia, 7 November 2020, diakses pada 8 November 2020, https://www.cnbcindonesia.com/news/20201107082302-4-200008/indonesia-resmi-resesi-inibuktinya-perihnya-di-masyarakat.

CNN Indonesia, "Kasus Covid-19 Indonesia Kembali Tertinggi di Asia Tenggara," 15 Oktober 2020, diakses pada 6 November 2020, https://www.cnnindonesia.com/internasional/20201015194430-106-558963/kasus-covid-19indonesia-kembali-tertinggi-di-asia-tenggara.

CNN Indonesia, "Kemenhan Pimpin Lumbung Pangan: Memori Orde Baru di Isu OMSP," 13 Juli 2020, diakses pada 6 November 2020, 
https://www.cnnindonesia.com/nasional/20200713093910-20-523889/kemenhan-pimpinlumbung-pangan-memori-Orde Baru-dan-isu-omsp.

CNN Indonesia, "Menkes Tantang Harvard Buktikan Virus Corona di Indonesia," 11 Februari 2020, diakses pada 6 November 2020, https://www.cnnindonesia.com/nasional/2020021119563720-473740/menkes-tantang-harvard-buktikan-virus-corona-di-indonesia.

"Coronavirus: Youthful Pakistan Appears to Avoid Worst of Pandemic." BBC News, 20 Agustus 2020, bag. Asia. https://www.bbc.com/news/world-asia-53742214.

Dagia, Niha. "How Did Pakistan Flatten the Coronavirus Curve?," 24 Agustus 2020. https://thediplomat.com/2020/08/how-did-pakistan-flatten-the-coronavirus-curve/.

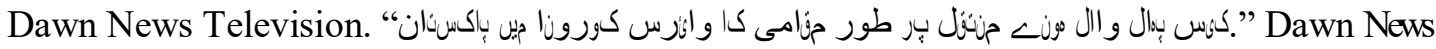
Television, 13 Maret 2020. https://www.dawnnews.tv/news/1122234.

DetikNews, "Timeline Setengah Tahun COVID-19 di Indonesia," 2 September 2020, diakses pada 6 November 2020, https://news.detik.com/berita/d-5156199/timeline-setengah-tahun-covid-19di-indonesia?single $=1$.

DetikNews, "Timeline Setengah Tahun COVID-19 di Indonesia," 2 September 2020, diakses pada 4 November 2020, https://news.detik.com/berita/d-5156199/timeline-setengah-tahun-covid-19di-indonesia?single $=1$.

Egi Adyatama, "Jokowi Buka Alasan Tunjuk Prabowo Pimpin Proyek Lumbung Pangan," Tempo.co, 13 Juli 2020, https://nasional.tempo.co/read/1364810/jokowi-buka-alasan-tunjuk-prabowopimpin-proyek-lumbung-pangan/full\&view $=$ ok.

Erik Prasetya, "Hari-hari jelang Reformasi, 20 tahun lalu, dalam gambar dan catatan," BBC, 21 Mei 2018, diakses pada 6 November 2020,

Floyd (2015) di M. Rizqi Isnurhadi, "Sekuritisasi Illegal, Unreported, Unregulated Fishing (IUUF) di Perairan Indonesia di Era Pemerintahan Joko Widodo," Jurnal Ilmu Hubungan Internasional, X(2), Juli-Desember 2017, hal. 125.

Giunchi, Elisa Ada. "THE POLITICAL AND ECONOMIC ROLE OF THE PAKISTANI MILITARY.” ISPI, ISPI Analysis, 269 (Juli 2014): 10.

Government of Pakistan. "COVID-19 Live Dashboard - Pakistan.” Google Data Studio. Diakses 3 November 2020. http://datastudio.google.com/reporting/1PLVi5amcc_R5Gh928gTE8-8r8fLXJQF/page/R24IB? feature $=$ opengraph.

Haris Prabowo, "Prabowo Subianto, Menhan 'Rasa' Mentan yang Urusi Lumbung Pangan,” Tirto.id, 15 Juli 2020, diakses pada 6 November 2020, https://tirto.id/prabowo-subianto-menhan-rasamentan-yang-urusi-lumbung-pangan-fQVc.

Hashim, Asad. “'Smart Lockdown' in Pakistan to Target 500 Coronavirus Hotspots,” 23 Juni 2020. https://www.aljazeera.com/news/2020/6/23/smart-lockdown-in-pakistan-to-target-500coronavirus-hotspots.

Hiski Darmayana, "Kemenkes Harus Sampaikah Langkah-langkah Preventif," Gesuri.id, 3 Maret 2020, diakses pada 7 November 2020, https://www.gesuri.id/pemerintahan/kemenkes-harussampaikan-langkah-langkah-preventif-b1YI5ZrA5.

Jaffery, Syed Ali Zia. "Pakistan's Fight Against COVID-19 Has Made Imran Khan Stronger," 15 September 2020. https://thediplomat.com/2020/09/pakistans-fight-against-covid-19-hasmade-imran-khan-stronger/.

Jamal, Sana. "COVID-19: Pakistan's Consistent Decline of New Infections Ends with 752 Cases 
Reported in One Day," 18 September 2020. https://gulfnews.com/world/asia/pakistan/covid19-pakistans-consistent-decline-of-new-infections-ends-with-752-cases-reported-in-one-day1.73956917.

Khalid, Atiqa, dan Sana Ali. "COVID-19 and Its Challenges for the Healthcare System in Pakistan." Asian Bioethics Review, 13 Agustus 2020. https://doi.org/10.1007/s41649-020-00139-x.

Kumparan, "Ahli Wabah UI: Kemenkes Salah Baca Undangan WHO, RI Belum Sukses Tangani Corona," 6 November 2020, diakses pada 7 November 2020, https://kumparan.com/kumparannews/ahli-wabah-ui-kemenkes-salah-baca-undangan-who-ribelum-sukses-tangani-corona-1uX21NTW9KL/full.

Lies, Yawen Chen, Elaine. "China Reports Big Rise in Coronavirus Deaths, WHO Sees No 'Tip of Iceberg." Reuters, 14 Februari 2020. https://www.reuters.com/article/us-china-healthidUSKBN207025.

Lisa Siregar, wawancara dengan Arif Zulkifli, Apa Kata Tempo, Eps. 40: “Acakadut Program Lumbung Pangan di Lahan Gambut," audio podcast, 13 Agustus 2020, https://open.spotify.com/episode/342IkMHfGOKR9aX5SWvCJ8?si=NPh4UzKzSK6a0smGv d8iJg.

Lisye Sri Rahayu, "JK: Indonesia Harus Preventif Hadapi Virus Corona, Urgen Pandemik Ini," DetikNews, 12 Maret 2020, diakses pada 5 November 2020, https://news.detik.com/berita/d4935783/jk-indonesia-harus-preventif-hadapi-virus-corona-urgen-pandemik-ini.

Mohammad Bernie, "Dwi Fungsi Saat Pandemi: Jokowi Melibatkan TNI untuk Tangani Corona," Tirto.id, 13 Agustus 2020, https://tirto.id/dwi-fungsi-saat-pandemi-jokowi-melibatkan-tniuntuk-tangani-corona-fXcx.

Muhammad Iqbal, "Virus Corona Lemah di Cuaca Panas? Ini Penjelasan IDI," CNBC Indonesia, 3 April 2020, diakses pada 5 November 2020, https://www.cnbcindonesia.com/news/20200403110351-4-149574/virus-corona-lemah-dicuaca-panas-ini-penjelasan-idi.

Nafees, Mohammad, dan Farukh Khan. "Pakistan's Response to COVID-19 Pandemic and Efficacy of Quarantine and Partial Lockdown: A Review." Electronic Journal of General Medicine 17, no. 6 (20 April 2020): em240. https://doi.org/10.29333/ejgm/7951.

Noreen, Nadia, Saima Dil, Saeed Niazi, Irum Naveed, Naveed Khan, Farida Khan, Shehla Tabbasum, dan Deepak Kumar. "COVID 19 Pandemic \& Pakistan; Limitations and Gaps." Global Biosecurity 1, no. 4 (21 Mei 2020). https://doi.org/10.31646/gbio.63.

“Pakistan's COVID-19 Crisis." Briefing. Karachi: International Crisis Group, 7 Agustus 2020. https://www.crisisgroup.org/asia/south-asia/pakistan/b162-pakistans-covid-19-crisis.

Pakistan Today Contributor. "Civil, military leadership working jointly against COVID-19: Fawad | Pakistan Today." Pakistan Today, 26 April 2020. https://www.pakistantoday.com.pk/2020/04/26/civil-military-leadership-working-jointlycovid-19-fawad/.

Rage Taufika, "Latent Securitisation of Illegal, Unreported, and Unregulated (IUU) Fishing in Indonesia," Global: Jurnal Politik Internasional, 22 (1): 34, doi: 10.7454/global.v22i1.488.

Remotivi, "Belajar dari Komunikasi Pemerintah: Menghadapi Pandemi Tanpa Empati," YouTube video, 8:10, 29 April 2020, https://www.youtube.com/watch?v=8EFv2kv_s8o

Shafi, Mohsin, Junrong Liu, dan Wenju Ren. "Impact of COVID-19 Pandemic on Micro, Small, and 
Medium-Sized Enterprises Operating in Pakistan.” Research in Globalization 2 (Desember 2020): 100018. https://doi.org/10.1016/j.resglo.2020.100018.

Shafqat, Saeed. "Pakistan Military: Sustaining Hegemony and Constructing Democracy?" Journal of South Asian and Middle Eastern Studies 42, no. 2 (2019): 20-51. http://www.jstor.org/stable/10.33428/jsoutasiamiddeas.42.2.0020.

Stritzel, Holger. "Securitization Theory and the Copenhagen School." Dalam Security in Translation: Securitization Theory and the Localization of Threat, disunting oleh Holger Stritzel, 11-37. New Security Challenges Series. London: Palgrave Macmillan UK, 2014. https://doi.org/10.1057/9781137307576_2.

Tangguh Chairil, "RESPONS PEMERINTAH INDONESIA TERHADAP PANDEMI COVID-19: DESEKURITISASI DI AWAL, SEKURITISASI YANG TERHAMBAT,” IR Binus, 23 Maret 2020, diakses pada 4 November 2020, https://ir.binus.ac.id/2020/03/23/responspemerintah-indonesia-terhadap-pandemi-covid-19-desekuritisasi-di-awal-sekuritisasi-yangterhambat/.

Umer, Hamza, dan Muhammad Salar Khan. Evaluating the Effectiveness of Regional Lockdown Policies in the Containment of Covid-19: Evidence from Pakistan, 2020. https://doi.org/10.31219/osf.io/s3fkp. 